\title{
LIMBAH AMPAS TAHU SEBAGAI BAHAN BAKU SUMBER PROTEIN NABATI PAKAN IKAN NAGAN RAYA
}

\author{
Farah Diana1, Ananingtyas SD² \\ 1Jurusan Akuakultur, Fakultas Perikanan dan Ilmu Kelautan, Universitas Teuku Umar \\ 2Jurusan Sumber Daya Akuatik, Fakultas Perikanan dan IImu Kelautan, Universitas Teuku Umar \\ Korespondensi : farahdiana@utu.ac.id
}

\begin{abstract}
ABSTRAK
Nagan Raya merupakan salah satu kabupaten di pantai barat Aceh dengan luas wilayah $311.480 \mathrm{Km} 2$, terdiri dari 9 kecamatan, 222 desa.Letak yang strategis tersebut, kemungkinan pengembangan bidang perikanan besar. Nagan Raya mulai mengembangkan bidang perikanan melalui perikanan budidaya. Pengabdian bagi masyarakat ini menggunakan metode pendampingan dan pembinaan melalui transfer pengetahuan berupa pelatihan dan praktek pembuatan pakan ikan menjadi produk pakan. Proses kegiatan yang sudah dilaksanakan dalam bentuk pendampingan dan pembinaan maka diklasifikasikan jenis luaran pada setiap tahapan yang dilalui yaitu; Mitra dapat membuat pakan ikan buatan dengan alternative limbah menggunakan mesin pelet, melakukan pengepakan dan pemasaran. Masyarakat di Nagan Raya juga memproduksi tahu sebagai olahan dari kacang kedelai, olahan ini akan menghasilkan limbah ampas tahu, yang saat ini belum termanfaatkan secara optimal. Bahan baku dari pelatihan ini adalah ampas tahu dan limbah ikan yang dikeringkan untuk diolah menjadi tepung pakan. Ampas tahu dipakai sebagai bahan pakan karena memiliki kelebihan selain kandungan nutrisi yang dimiliki juga memanfaatkan limbah pengolahan sehingga pencemaran lingkungan dapat dihindarkan. Limbah tahu ini merupakan bahan alternative bahan baku pakan ikan yang ramah lingkungan. Karena terbuat dari sisa pengolahan industri tahu. Secara konseptual dan aplikasi transfer ipteks dilakukan melalui: aspek teknik pembuatan pakan ikan dan aspek pemasaran.
\end{abstract}

Kata kunci: Ampas tahu, sumber protein, nagan raya

\begin{abstract}
Nagan Raya is one of the districts on the west coast of Aceh with an area of 311,480 $\mathrm{km} 2$, consisting of 9 districts, 222 villages. The strategic location, the possibility of developing a large fishery field. Nagan Raya began to develop the field of fisheries through aquaculture. Devotion to this community using the method of mentoring and coaching through knowledge transfer in the form of training and practice of making fish feed into feed products. Process activities that have been implemented in the form of mentoring and coaching then classified the type of output at each stage that is passed; Partners can make artificial fish feed with waste alternatives using pellet machines, packing and marketing. Communities in Nagan Raya also produce tofu as processed from soybeans, this preparation will produce waste of tofu waste, which is currently not utilized optimally. The raw material of this training is the tofu and waste waste of dried fish to be processed into feed powder. Tofu waste is used as a feed ingredients because it has advantages in addition to the nutrient content owned also utilize waste processing so that environmental pollution can be avoided. Waste know this is an alternative material of raw materials of environmentally friendly fish feed. Because it is made from waste processing industry residue. Conceptually and the application of science transfer transfer is done through: aspects of fish feed manufacturing techniques and marketing aspects.
\end{abstract}

Keywords: The tofu, the source of protein, nagan raya

\section{PENDAHULUAN}

Kebutuhan ikan sebagai konsumsi manusia, selain diperoleh dari tangkapan alami, juga diperoleh dari hasil budidaya. Usaha budidaya yang semakin luas bertujuan untuk mencukupi kebutuhan konsumsi ikan seiring dengan pertambahan jumlah 
penduduk. Dampak yang selanjutnya akan muncul adalah tuntutan produksi ikan yang semakin tinggi. Dalam usaha budidaya ikan, perlu diperhatikan tentang penyediaan benih dan pakan yang cukup memadai baik secara kuantitas maupun kualitas. Untuk memperoleh produksi ikan yang maksimal, antara lain dapat dicapai melalui system budidaya intensif. Menurut Djajasewaka (1985), budidaya ikan yang intensif merupakan suatu usaha pemeliharaan ikan dengan padat penebaran tinggi dan keharusan memberi pakan buatan.

Permasalahan yang sering dihadapi dalam penyediaan pakan buatan ini adalah biaya yang cukup tinggi untuk penyediaan pakan. Menurut Rasidi (1998), biaya pakan ini dapat mencapai $60-70 \%$ dari komponen biaya produksi. Salah satu alternatif yang dapat dilakukan untuk menekan biaya produksi tersebut adalah dengan membuat pakan buatan sendiri. Pembuatan pakan buatan ini menggunakan teknik yang sederhana dengan memanfatkan sumber- sumber bahan baku lokal, termasuk pemanfaatan limbah hasil industri pertanian yang relatif murah.

Kabupaten Nagan Raya merupakan salah satu kabupaten di pantai barat Aceh dengan luas wilayah $311.480 \mathrm{Km}^{2}$, terdiri dari 9 kecamatan, 222 desa dengan posisi $2^{\circ}-5^{\circ}$ Lintang Utara dan $25^{\circ}-97^{\circ} 10^{\prime}$ Bujur Timur, dengan batas batas: sebelah utara berbatasan dengan Kabupaten Aceh Tengah, sebelah selatan berbatasan dengan Samudera Hindia dan Kabupaten Aceh Barat Daya, sebelah timur berbatasan dengan Kabupaten Gayo Lues dan Kabupaten Aceh Barat Daya serta sebelah barat berbatasan dengan Kabupaten Aceh Barat.

Berdasarkan letak yang strategis tersebut, kemungkinan pengembangan bidang perikanan besar. Terbukti saat ini Nagan Raya mulai mengembangkan bidang perikanan melalui perikanan budidaya. Selain itu masyarakat di Nagan Raya juga memproduksi tahu sebagai olahan dari kacang kedelai. Olahan ini akan menghasilkan limbah ampas tahu, yang saat ini belum termanfaatkan secara optimal. Bahkan limbah ampas tahu ini hanya menjadi limbah olahan pertanian dan dibuang di perairan, yang akan berakibat terhadap pencemaran lingkungan. Untuk itu perlu adanya pembinaan yang bersifat berkelanjutan untuk menangani limbah yang tidak termanfaatkan menjadi produk yang bernilai tinggi. Keterbatasan pengetahuan mengenai cara pengolahan limbah sebagai bahan baku pakan dan kurangnya pengetahuan teknik pembuatan pakan.

Peluang usaha yang besar karena potensi daerah sebagai daerah pesisir yang mempunyai hasil tangkap berlebih merupakan sumber bahan baku pembuat pakan ikan selain ampas tahu yang merupakan limbah olahan. Potensi ini merupakan peluang yang besar untuk produksi tepung ikan dan tepung ampas tahu yang selanjutnya akan diolah menjadi pakan ikan dan menjadi usaha kecil berbasis masyarakat. Produksi pembuatan pakan ikan ini akan menghidupkan industri di lingkungan masyarakat dengan bidang usaha pembuatan bahan baku pakan dan pembuatan pakan ikan. Secara tidak langsung usaha pembuatan pakan ikan yang ada akan menjadi trigger untuk berkembangnya usaha yang lain. Hal ini akan menjadikan social masyarakat bergeliat dalam peningkatan usaha. Dampak yang langsung adalah dengan produksi pakan ikan yang mulai tumbuh dan berkembang akan membuka peluang warga masyarakat membuka usaha budidaya ikan. Dalam rantai usaha keberadaan 
pembuatan pakan ikan ini mendorong alur pemasaran yang pada akhirnya akan menambah daya serap tenaga kerja melalui usaha ini.

Kelayakan usaha ini karena bahan baku pakan ikan tersedia di local setempat dan bahan limbah maka akan memberikan keuntungan yang cukup berdampak pada kesejahteraan masyarakat.

\section{Masalah}

Pada saat ini pengolah/pembuat pakan ikan menghadapi masalah sebagai berikut :

a. Kelompok pengolah/pembuat pakan ikan masih mengalami kesulitan untuk memanfaatkan limbah sebagai bahan baku alternative pakan ikan.

b. Informasi tentang teknik pembuatan pakan ikan secara benar belum dikuasai

c. Belum terbentuknya pola pemasaran dari produk pakan yang dihasilkan.

d. Informasi pasar yang dikuasai sangat terbatas dan wilayah pemasarannya masih terbatas.

e. Masih perlunya pendampingan dalam memproduksi pakan dari proses persiapan hingga pemasaran.

f. Tidak seimbangnya biaya pakan ikan sebagai biaya produksi dalam pembesaran ikan, karena mitra selain akan mengembangkan produksi pakan buatan sekaligus mengembangkan budidaya ikan.

\section{Target Luaran}

Melalui pendampingan wirausaha pembuatan pakan ikan, kelompok pembuat pakan akan memiliki ketrampilan dalam hal pembuatan pakan ikan menjadi produk pakan dan membangun kewirausahaan sehingga mereka mampu menjadi kelompok yang mandiri. Selain itu diharapkan kelompok wirausaha pembuat pakan ikan ini dapat menjadi motivasi bagi masyarakat yang lain untuk melakukan hal yang sama sehingga usaha pembuatan pakan ikan dapat berkembang yang berdampak signifikan terhadap peningkatan pendapatan dan kesejahteraan keluarga secara berkelanjutan. Adapun target luaran IbM ini secara rinci adalah:

1. Mengembangkan usaha kecil masyarakat melalui pembuatan pakan ikan. Usaha pembuatan pakan ikan skala kecil-menengah ini dapat memproduksi pakan ikan untuk memenuhi kebutuhan local wilayah bahkan luar wilayah produksi. Kondisi ini dikarenakan wilayah lain belum ada kelompok pembuat pakan ikan. Pakan ikan yang diproduksi akan dilengkapi kadar protein pakan sesuai dengan permintaan pasar yang biasanya membeli pakan ikan buatan pabrik.

2. Memanfaatkan limbah hasil olahan menjadi produk yang mempunyai nilai jual tinggi. Pemanfaatan limbah ampas tahu sebagai bahan baku pakan ikan pensuplai protein nabati akan menjadi sebuah solusi besar terhadap dampak limbah industry pembuatan tahu yang selama ini dibuang tanpa dimanfaatkan secara optimal. Selain itu permasalahan pencemaran lingkungan baik tanah, air dan udara juga dapat diatasi dengan penggunaan ampas tahu sebgai bahan dasar pakan ikan. Hal ini juga dapat menaikkan harga jual ampas tahu karena yang biasanya dibuang tanpa memiliki nilai ekonomis, setelah diolah nilai ekonomis ampas tahu ini akan menjadi lebih tinggi. Nilai ekonomis yang naik akan berdampak pada peningkatan kesejahteraan pembuat pakan ikan, pengrajin tahu bahkan masyarakat sekitar 
yang secara langsung ataupun tidak ikut serta dalam rantai produksi dan distribusi.

3. Menjadikan limbah ampas tahu menjadi bahan baku alternative pakan ikan. Kandungan protein ampas tahu dari berbagai literature berada pada kisaran $19-24 \%$ sehingga memungkinkan digunakan sebagai bahan substitusi pada tepung kedelai sebagai sumber protein nabati pada pakan. Mahalnya tepung kedelai membuat para pembuat pakan ikan berfikir untuk produksi karena jika kebutuhan protein nabati pakan tetap disuplai dari kedelai maka harga pakan pun akan tinggi dan bias jadi hargaakan sama dengan pakan buatan pabrik. Alternatif bahan baku limbah ini mempunyai daya jual sendiri terhadap lingkungan tempat lokasi industry tahu dan industry pakan buatan.

4. Tersedianya buku ajar pembuatan pakan ikan untuk pendampingan kelompok pembuat pakan ikan. Terbitnya buku ajar pembuatan pakan ikan dari bahan alternatif sebagai modul/panduan pembuatan pakan ikan dari ampas tahu. Hal ini dilakukan sekaligus dengan bimbingan teknis selama pengabdian dilakukan. Buku ajar ini akan dibuat disesuaikan dengan realitas dilapangan.

5. Tersedianya pakan ikan dengan label kandungan gizi yang sudah diuji dan di patenkan. Produk pakan ikan yang sudah diproduksi akan dilakukan uji kimia dan uji biologi agar benar-benar layak diproduksi secara missal, sehingga mempunyai brand sendiri dan dipatenkan untuk diproduksi oleh daerah lokasi pengabdian.Publikasi ilmiahAdalah merupakan sarana publikasi dan pengenalan tentang hasil program yang sudah diterapkan sehingga dapat dijadikan informasi bagi kelompok di wilayah lain yang mempunyai potensi sumberdaya alam yang sama. Dan memberikan contoh wirausaha pembuatan pakan ikan seara kecil dalam usaha peingkatan kesejahteraan.

\section{Solusi yang ditawarkan}

Terkait permasalahan mitra dibutuhkan solusi dalam aspek :

a. Peningkatan kemampuan /ketrampilan teknis pembuatan pakan ikan melalui pelatihan pembuatan pakan ikan dengan menggunakan mesin pembuat tepung dan pellet ikan yang benar dari persiapan hingga packing.

b. Pembuatan pakan ikan menjadi produk pakan yang berkelanjutan sehingga dapat meningkatkan pendapatan keluarga.

c. Membuka peluang pemasaran dengan menghubungkan kelompok pembuat pakan ikan dengan pembudidaya ikan skala lokal atau luar wilayah kabupaten.

d. Pemberian bantuan alat dan bahan untuk pembuatan pakan ikan seperti blender, mesin pembuat tepung untuk menghaluskan ikan, ampas tahu, mesin pembuat pakan, ember plastik, timbangan, nampan penjemur, plastik packing,

e. Peningkatan kualitas mutu pakan ikan melalui pelatihan terkait persiapan bahan baku, formulasi pakan dan teknik pembuatan pakan serta kestabilan jumlam produksi.

f. Peningkatan kapasitas pembuat pakan ikan melalui pelatihan terkait dengan kewirausahaan yang mencakup Analisis Pasar dan Strategi Pemasaran. 


\section{METODOLOGI}

Pengabdian bagi masyarakat ini menggunakan metode pendampingan dan pembinaan melalui transfer pengetahuan berupa pelatihan dan praktek pembuatan pakan ikan menjadi produk pakan. Pengabdian ini akan dilaksanakan di Gampong Ujong Blang Kecamatan Betong Kabupaten Nagan Raya selama 10 bulan masa pendampingan dan pembinaan. Penerapan Ipteks dilakukan dengan beberapa tahapan meliputi:

\section{a. Tahap Persiapan}

Tahap ini dilakukan untuk persiapan secara menyeluruh dari mitra dan timpendamping dengan melakukan persiapan bahan baku dan dilakukan uji laboratorium atas kelayakannya sebagai bahan baku. Persiapan bahan baku dari bahan menjadi bahan setengah jadi dengan alat penepung yang akan diberikan kepada kelompok pembuat pakan ikan.

b. Tahap Pelaksanaan

Tahap ini akan dilakukan proses pembuatan pakan ikan dengan mesin pembuat pakan ikan yang akan diberikan pada kelompok pembuat pakan ikan. Tahap pelaksanaan program ini akan dilakukan seluruh kegiatan pembuatan pakan dengan mesin.

c. Tahap akhir Pelaksanaan

Tahap ini merupakan tahap tingkat akhir dari seluruh proses pendampingan yang dilakukan, selain standarisasi pengepakan yang sudah dilakukan pelatihan di tahap pelaksanaan maka tahap ini kelompok pembuat pakan akan di damping dalam pemasaran dan brand local pakan ikan yang sudah diproduksi jika memungkinkan formuulasi yang ada akan di patenkan tentang penggunaan pakan untuk jenis ikan yang sesuai. 


\section{HASIL DAN PEMBAHASAN}

Kabupaten Nagan Raya merupakan salah satu kabupaten di pantai barat Aceh dengan luas wilayah $311.480 \mathrm{Km}^{2}$, terdiri dari 9 kecamatan, 222 desa dengan posisi $2^{\circ}-5^{\circ}$ Lintang Utara dan $25^{\circ}-97^{\circ} 10^{\prime}$ Bujur Timur, dengan batas batas: sebelah utara berbatasan dengan Kabupaten Aceh Tengah, sebelah selatan berbatasan dengan Samudera Hindia dan Kabupaten Aceh Barat Daya, sebelah timur berbatasan dengan Kabupaten Gayo Lues dan Kabupaten Aceh Barat Daya serta sebelah barat berbatasan dengan Kabupaten Aceh Barat.

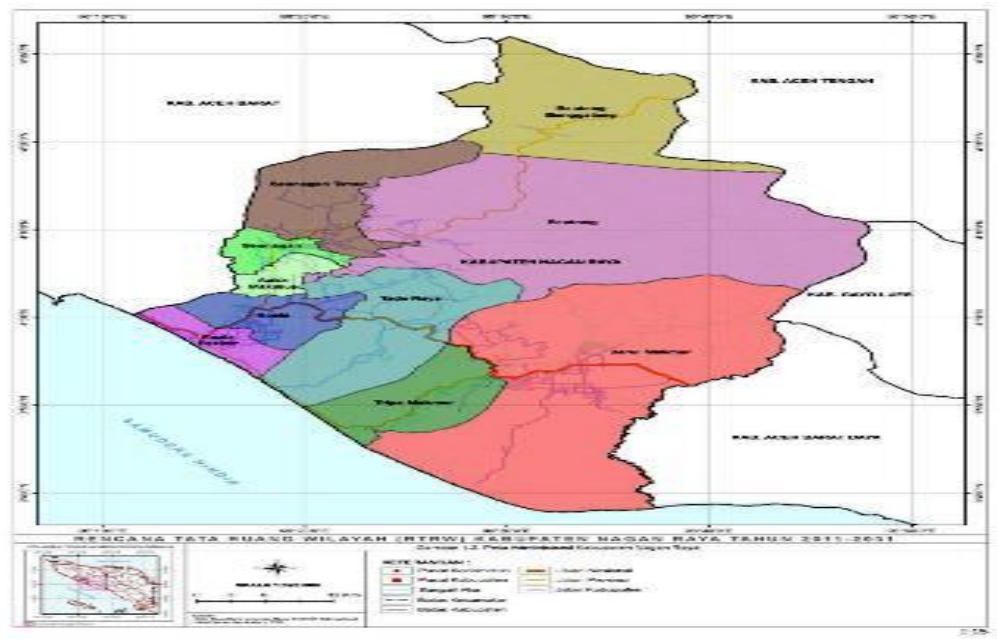

Gambar 1. Kabupaten Nagan Raya

Berdasarkan letak yang strategis tersebut, kemungkinan pengembangan bidang perikanan besar. Terbukti saat ini Nagan Raya mulai mengembangkan bidang perikanan melalui perikanan budidaya. Selain itu masyarakat di Nagan Raya juga memproduksi tahu sebagai olahan dari kacang kedelai. Olahan ini akan menghasilkan limbah ampas tahu, yang saat ini belum termanfaatkan secara optimal. Bahkan limbah ampas tahu ini hanya menjadi limbah olahan pertanian dan dibuang di perairan, yang akan berakibat terhadap pencemaran lingkungan. Berdasarkan hasil pengabdian yang dilakukan oleh tim IbM menunjukkan bahwa di gampong Krueng Kec. Beutong memiliki potensi yang sangat bagus untuk pengembangan pakan ikan, karena Gampong tersebut merupakan tempat pembudidaya ikan berbagai jenis.

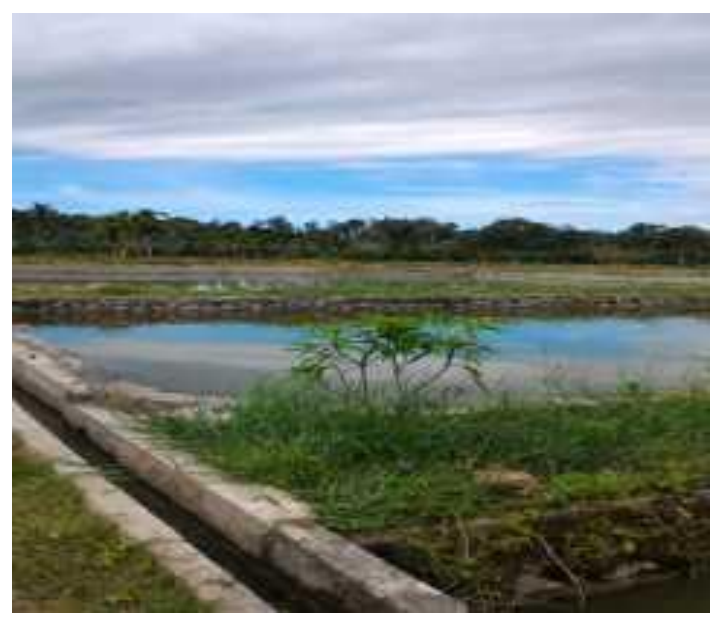

Gambar 2. Lokasi pembuatan pakan ikan 
Lokasi ini sangat cocok dengan pelatihan pembuatan pakan ikan, dan merupakan letak yang stratergis untuk pembuatan pakan ikan. Adapun bahan baku dari pelatihan ini adalah ampas tahu dan limbah ikan yang dikeringkan untuk diolah menjadi tepung pakan. Kegiatan ini sangat bermanfaat bagi masyarakat sekitarnya dalam hal ini limbah yang dihasilkan bisa diolah menjadi pakan buatan. Pakan buatan sangat banyak proteinnya, sehingga pertumbuhan ikan semakin meningkat. Ampas tahu merupakan limbah industri pembuatan tahu yang pada saat ini masih belum termanfaatkan secara optimal. Ampas tahu ini merupakan bahan sumber protein nabati yang berfungsi mensuplai kandungan protein nabati pada pakan ikan. Ampas tahu digunakan sebagai bahan alternative karena selain merupakan penyebab limbah di perairan ataupun didarat juga masih memiliki kandungan nutrisi pakan yang berguna untuk pembesaran ikan.
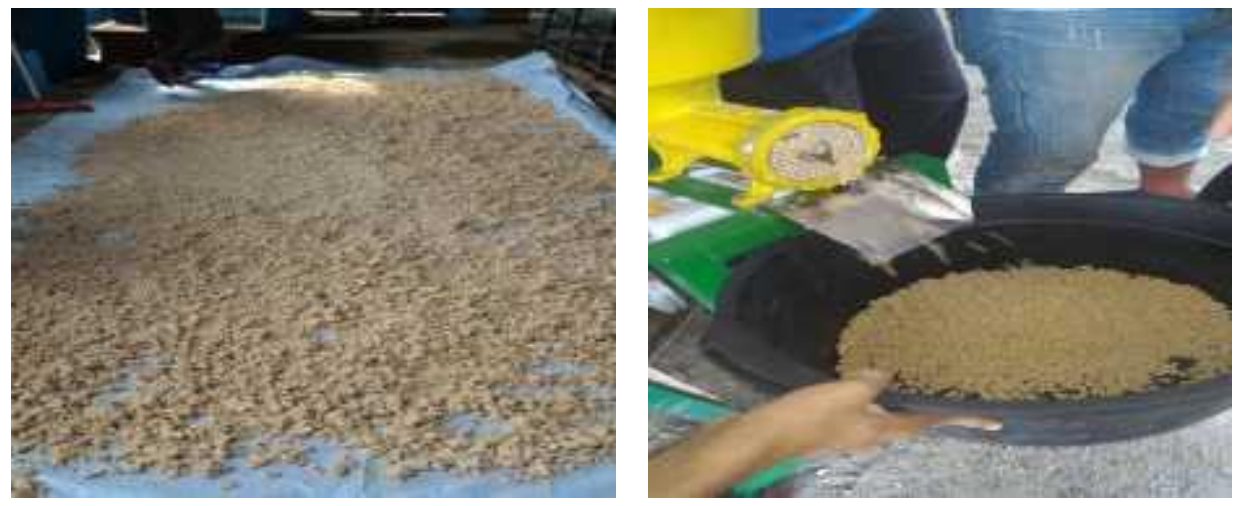

Gambar 3. Ampas Tahu sebelum diolah jadi tepung

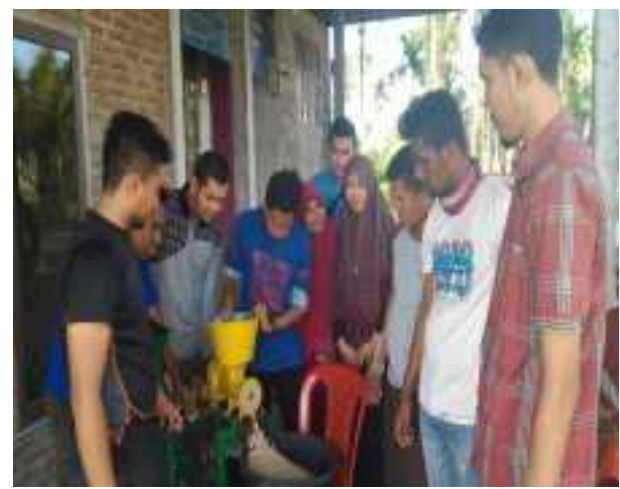

Gambar 4. Proses pembuatan dan penjemuran pakan

Ampas tahu dipakai sebagai bahan pakan karena memiliki kelebihan selain kandungan nutrisi yang dimiliki juga memanfaatkan limbah pengolahan sehingga pencemaran lingkungan dapat dihindarkan. Selanjutnya, ampas tahu ini akan di olah menjadi tepung tahu, yang selanjutnya akan dibuat formulasi sebagai bahan baku pakan buatan. 

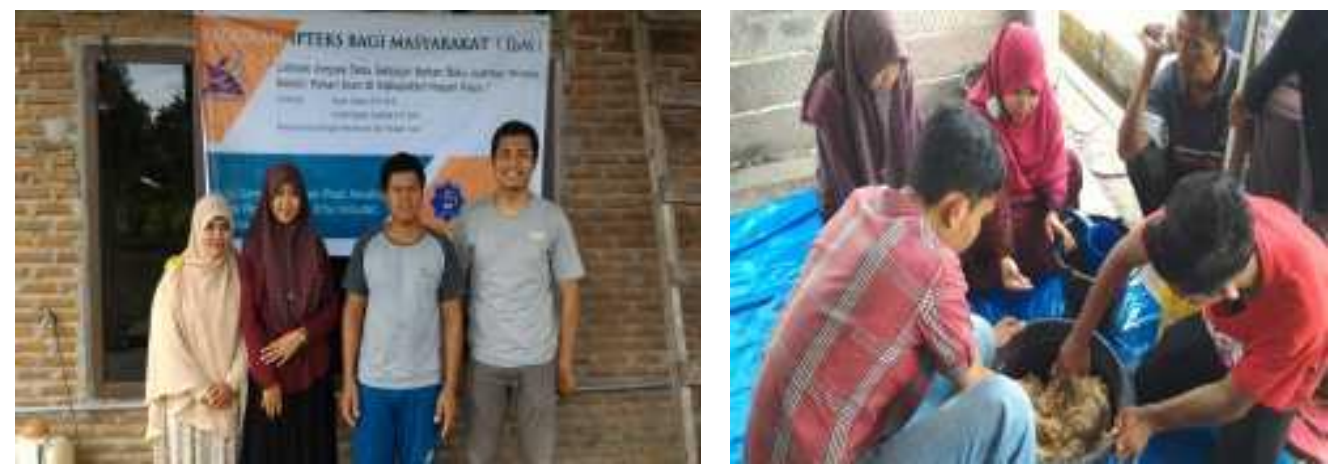

Gambar 5. Menjadi desa binaan pembuatan pakan

Limbah tahu ini merupakan bahan alternative bahan baku pakan ikan yang ramah lingkungan. Karena terbuat dari sisa pengolahan industri tahu. Dan merupakan bentuk diversifikasi hasil olahan pada industry rumah tangga di lokasi penelitian. Transfer ipteks yang lain adalah penggunaan mesin tepung, mesin pellet, dan packing hasil produksi pakan ikan oleh kelompok pembuat pakan ikan. Selanjutnya tepung ampas tahu diproses menjadi pakan ikan dengan menggunakan alat pembuat pakan sederhana. Secara konseptual dan aplikasi transfer ipteks dilakukan melalui :

\section{Aspek Teknik Pembuatan Pakan Ikan}

1. Persiapan bahan baku pakan

Bahan baku pakan yang dipersiapkan dan sudah diuji analisis proksimat terlebih dahulu adalah :
a. Tepung ikan
b. Tepung kedelai
c. Tepung ampas tahu
d. Tepung tapioca
e. Premix

Kandungan nutrisi masing-masing bahan dari berbagai sumber disajikan pada tabel 1 berikut ini:

\begin{tabular}{l|c|c|c|c|}
$\begin{array}{l}\text { tabel 1 berikut ini: } \\
\text { Komposisi }\end{array}$ & Tepung ikan & $\begin{array}{c}\text { Tepung } \\
\text { kedelai }\end{array}$ & $\begin{array}{c}\text { Tepung } \\
\text { ampas tahu }\end{array}$ & Tapioka \\
\hline Kadar kering & 93 & 86.53 & 88.91 & 85.84 \\
Protein & 59,58 & 30.71 & 19.30 & 0.00 \\
Lemak & 6.89 & 11.40 & 3.46 & 0.00 \\
Karbohidrat & 4.12 & 35.97 & 41.49 & 0.00 \\
Serat kasar & 4.48 & 2.82 & 20.61 & 0.00 \\
Abu & 17.93 & 5.63 & 3.87 & 0.00 \\
Energi (kka1/gr) & - & 4.32 & 4.21 & 4.21 \\
Sumber diolah dari Darsudi (2011) dan Septia (1999) & &
\end{tabular}


2. Persiapan Pembuatan Pakan

Persiapan alat :
a. Mesin pakan ikan
b. Timabangan
c. Nampan
d. Mesin pembuat tepung
e. Kayu pengaduk
f. Ember plastik
g. Terpal alas
h. Para-para jemur

3. Persiapan Lokasi "mini show room"

4. Pembuatan pakan dengan prosedur:

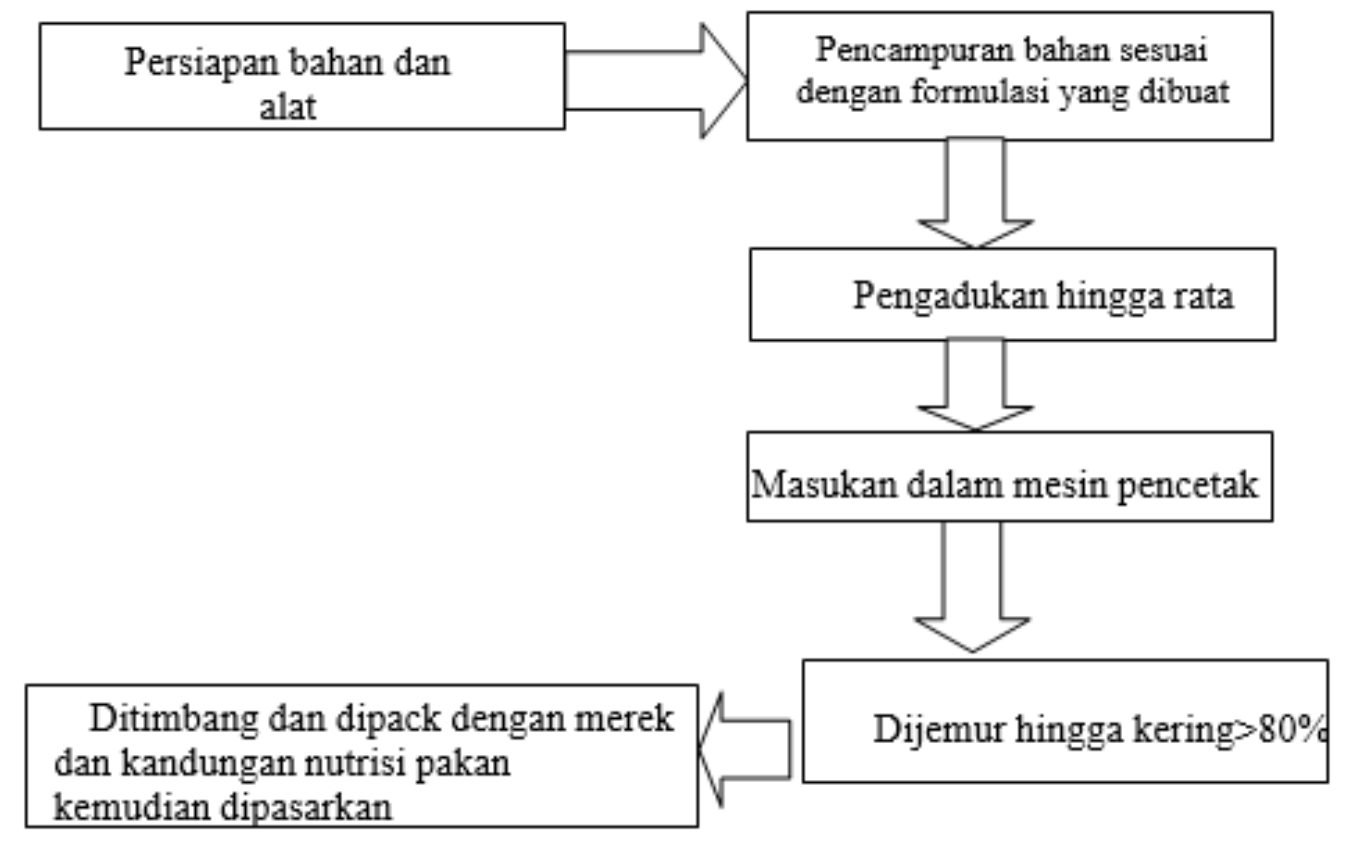

\section{Aspek Pemasaran}

Pemasaran produk perikanan dapat diartikan sebagai suatu proses jalannya hasil produksi hingga diterima oleh konsumen. Proses aktivitas pemasaran dilakukan dengan mengidentifikasi pasar sasaran, menentukan kebutuhan konsumen dalam pasar tersebut, dan memilih kombinasi yang tepat dari strategi, harga, promosi dan distribusi yang dikenal sebagai bauran pemasaran. Sedangkan strategi pemasaran adalah gambaran yang dilakukan perusahaan dalam pasar tertentu. Strategi pemasaran merincikan pasar target dan bauran pemasaran. Dimana target pasar adalah sekelompok konsumen yang homogen yang dihimbau perusahaan sedangkan bauran pemasaran adalah sejumlah variabel yang dapat dikendalikan yang digabungkan perusahaan untuk memenuhi kebutuhan kelompok target. Secara umum strategi pemasaran meliputi segmentasi pemasaran, penentuan berbagai pasar, strategi marketing mix, s trategi memasuki pasar, strategi penentuan waktu. 


\section{KESIMPULAN DAN SARAN}

\section{Kesimpulan}

Berdasarkan hasil pengabdian yang dilakukan di Gampong teupok Kreung Kabupaten Nagan Raya dapat disimpulkan bahwa ibM limbah dari ampas tahu sangat baik diterapkan sebagai pakan alternative untuk meningkatkan pertumbuhan ikan, dan juga harga relatif murah bagi masyarakat Nagan sendiri.

Saran

IbM limbah dari ampas tahu ini tetap dilanjutkan kedepan, diharapkan lebih bisa diterapkan sebagai pakan ikan yang berkelanjuta dan bisa di produksi untuk seterusnya oleh masyarakat setempat.

\section{DAFTAR PUSTAKA}

Djajasewaka, H. 1985. Pakan Ikan (Makanan Ikan). Edisi II. Jakarta: Penerbit CV Yasaguna.

Darsudi. 2011 dalam Matharini. Analisis Proksimat Tepung Ikan. http://dwitiyamartharini.blog.ugm.ac.id/2012/08/13/analisis-proksimat-tepung-ikan/ download 28 April 2015

Rasidi. 1998. Formulasi Pakan Lokal Alternatif Untuk Unggas. Jakarta: Penebar Swadaya.

Septia, A.D, 1999. Pengaruh Pemberian Silase Ampas Tahu Sebagi Sumber Protein nabati Pengganti Tepung Kedelai Terhadap Kelulushidupan dan Pertumbuhan Benih Bawal Air tawar (Colossomma macropomum). Skripsi. Universitas Brawijay Malang 